\section{Tryst with Fitness}

One fine morning in February 2017, having coffee with Dr. Ajay Handa, our pulmonologist, he brought to notice my regular yawning during the conversation. Further queries such as snoring during sleep suggested that I should get my assessment for a possible sleep apnea. The result of the testing was scary - I was bordering on obstructive sleep apnea! This set the alarm bells ringing and that's when started some lifestyle changes to reduce weight as the initial effort.

I had never been an athlete or a sports enthusiast during my life so far. As a result, any form of exercise was more of "self-torture." Even during the early days in armed forces, any form or distance of running was abhorring. However, the mindset changed when the needs were altered. I started earnestly to shed some pounds off and this included regular physical activity in the form of running and mild weight training. The reality hit me in the face - I could hardly run $500 \mathrm{~m}$ before a halt, panting, and walking for a few meters before trying to run again. Coupled to these efforts was diet control (Not dieting!!).

The human body has enormous capacity, and one has to just realize its potential. I have tried to lose weight earlier in life too, but then I was in my thirties when the basal metabolic rate is still on the higher side, and it was much easier. However, as you get into the forties, the weight gain is so much easier and loss, an arduous task. However, persistence in the efforts increased my running endurance over time. At the age of 43, I actually celebrated the first time I ran $5 \mathrm{~km}$ without a halt!! When I look back at it, it does make me smile!

Within 3 months, I had made some difference to my weight and started feeling much lighter. The running distances increased to $10 \mathrm{~km}$ at a slow pace and eventually tried my first shot at a half-marathon. Not the best of training prior but was able to finish it without any injuries. This brought in a new belief about my ability to run and the wonderful physical activity that running is. Participation in various running events of varying distances increased over the next year. I was bitten by the running bug!

There are icons and figures you follow in various spheres of our life- a senior in college, a senior faculty member, a renowned figure in our field of practice, etc. Yes, I did have such figures in running too. Among my friends and seniors who ran was Col. J Muthukrishnan SM (A gallantry award winner - Sena Medal!). Shifting to Pune made me follow him even more closely, being in the same department.
This is when I learnt the science behind running. There is so much more to running than just putting on shoes and putting one foot ahead of the other. He introduced me to his coach and mentor, Mr. Ashok Nath (popularly known as Ash!). A workshop with Ash at Mumbai stirred up a new desire to improve my running form. I enrolled as his mentee and this gave me a new look at myself and my abilities. Nutrition, fueling during a run, importance of recovery after a run, sleep, efficient running form, etc., were areas I had no clue about. Following his plans made me realize my dream of running a half-marathon in under $2 \mathrm{~h}$ ! This was a revelation and will be remembered forever. I recently went on to run my first full marathon, an achievement beyond my belief when I started running.

Over the couple of years in the tryst with fitness, I have realized that there are a few rules and commitment is a must. One of the rules of weight loss is simple mathematics. To achieve $1 \mathrm{~kg}$ weight loss, one needs to lose $7700 \mathrm{Kcal}$. Assuming a net negative balance of $100 \mathrm{kcal}$ per day, this target of $7700 \mathrm{kcal}$ will be achieved not before 10-12 weeks that's nearly 3 months! Moreover, this is where commitment to the physical activity for this duration is needed. More the negative balance in calories earlier will the results be achieved. The second rule is that it takes at least 3 weeks for an activity to become a habit.

To achieve weight loss, one needs to engage in any physical activity which increases heart rate (aerobic exercises) and sustains it for at least $30 \mathrm{~min}, 3-4$ times a week. Start slow at first, $10-15 \mathrm{~min}$ initially, and gradually increase by $5 \mathrm{~min}$ every 2-4 weeks. The Frequency-Intensity-Time-Type (FITT) principle is an interesting way to plan the workouts. ${ }^{[1]}$ The other kind of exercises is called Resistance Exercise, which involves weight training. Here too, the FITT principle can help strategize the workout. These should be done at least 2 days a week. You build muscle over a period and this burns fat, Voila! It is good to get a good physical examination before you are starting an exercise program. Get some basic coaching for your physical activity and have a buddy to help you with the early days till it becomes a habit. Cheers to fitness!

\section{Financial support and sponsorship}

Nil.

Conflicts of interest

There are no conflicts of interest. 


\section{TVSVGK Tilak}

Department of Internal Medicine, AFMC, Pune,

Maharashtra, India

Address for correspondence: Dr. TVSVGK Tilak, AFMC, Pune, Maharashtra, India.

E-mail:drtilaktvs@gmail.com

Submitted: 24-Dec-2019

Accepted in Revised Form: 06-Jan-2020

Published: 17-Feb-2020

\section{Reference}

1. Pescatello L, Arena R, Riebe D, Thompson P. General Principles of Exercise Prescription. In: ACSM's Guidelines for Exercise Testing and Prescription. $9^{\text {th }}$ ed. Philadelphia: Wolters Kluwer Health/Lippincott Williams and Wilkins; 2013. p. 166-77.
This is an open access journal, and articles are distributed under the terms of the Creative Commons Attribution-NonCommercial-ShareAlike 4.0 License, which allows others to remix, tweak, and build upon the work non-commercially, as long as appropriate credit is given and the new creations are licensed under the identical terms.

\begin{tabular}{|l|l|}
\hline \multicolumn{2}{|c|}{ Access this article online } \\
\hline Quick Response Code: & Website: \\
& www.ijmpo.org \\
\cline { 2 - 2 } & DOI: \\
\hline
\end{tabular}

How to cite this article: Tilak TV. Tryst with fitness. Indian J Med Paediatr Oncol 2019;40:563-4. 